\title{
The Development of Thematic Learning Video Media on Theme Clean Air for Health in Primary School
}

\author{
Luki Sablimai \\ Pendidikan Dasar \\ Pascasarjana Unimed \\ Medan, Indonesia \\ lukisablimai@gmail.com
}

\author{
Ibnu Ha1jar \\ Pendidikan Dasar \\ Pascasarjana Unimed \\ Medan,Indonesia
}

\author{
Hidayat \\ Pendidikan Dasar \\ Pascasarjana Unimed \\ Medan,Indonesia
}

\begin{abstract}
The Development of Thematic Learning Video Media on Theme Clean Air for Health In Primary School. The purpose of this study were: Developing thematic learning media theme of clean air air for health in primary school that deserved to be applied as learning media as learning resource, and knowing the effectiveness of thematic learning media video theme of clean air for health in primary school as learning media as a learning resource. This research was $R \& D$ (Research and Develepoment) by implementing the procedure of Borg and Gall. The research stages are: validation of material experts, media experts, learning design experts, and product trials. The product trial had three stages: individual trials which involve 3 students, small group trial which in 9 students, and operational trial which involved 30 people. The result of this research showed that learning video media was worhty to use as learning media after being validated by material expert, media expert, learning design expert, and product trials. The average score of the material expert was 4 , it meant "good". The average score of the media expert iwas 3,33 , it meant "good". The average score of the learning design was 3,1 , it meant "good". The score of individual trial was 2,68 , it meant "good". The score of small group trial was 3,1, it meant "good". The final product of this learning video media is proved with the effectiveness exam. The study takes place in SD (primary school) 101732 Kampung Lalang in grade 5 . The samples are 50 students consisting of 25 students as a class are treated using thematic learning video and 25 students as the class that use the learning as usual. The result prove that there is a significant difference between the learning outcomes of students that learned using video media.

Keywords: Video Media, Thematic Learning
\end{abstract}

\section{INTRODUCTION}

The importance of education in life was the main reason for carrying out a learning process. Learning was an effort to learn a person or group of people through various efforts and various strategies, methods and approaches towards achieving the planned goals ${ }^{1}$.

As a teacher, the teacher was not only responsible for teaching his students, but also must prepared interesting learning tools. The learning tools include syllabus, lesson plans, and learning media. Teacher's creativity in designing learning tools greatly affected whether or not learning objectives were achieved. Learning media was one component that could not be ignored in developing a quality teaching system. Learning media was a medium that could be conveyed learning messages or content to teach someone. In the learning process the use of instructional media will greatly help smoothness in achieving learning goals ${ }^{2}$.

Based on observations and interviews in class 5 SD (primary school) Kampung Lalang, it was known that the intensity of the use of learning video media in learning using the 2013 curriculum was still lacking due to several factors, including teachers being less able to apply the 2013 curriculum learning because it was different from the previous curriculum so that media selection learning was not in accordance with the theme, the use of IT-based media such as videos in learning according to the 2013 curriculum had never been done, and the limited time for teachers to develop media.

Based on the background of the above problems, the formulation of the problem were as follows: How was the process of developing thematic learning video media the theme of clean air for proper health for class 5 SD 101732 Kampung Lalang?, and was the use of thematic learning video media the theme of clean air for health effective to be used in class 5 students of SD 101732 Kampung Lalang?

The objectives expected in this study are: Developing thematic learning video media on the theme of clean air for health for grade 5 students of SD 101732 Kampung Lalang which was feasible to be applied as a learning medium as a learning resource. Knowing the effectiveness of thematic learning video media on the theme of clean air for health in grade 5 students of SD 101732 Kampung Lalang as learning media as learning resources.

\section{METHOD}

This type of research was the development of the Borg \& Gall model. These steps of research and development could be broadly summarized into 5 main steps. First, needs analysis. Needs analysis was conducted for all grade 5 students and class teachers to find out the needs of students and teachers regarding the use of media, especially video media. Second, reviewing competency standards and learning materials that would later be developed. Third, the development of learning programs. Learning programs were developed based on video media products implemented into RPP, development was 
carried out by analyzing learning resources, determining themes and sub-themes and analyzing student characteristics. Fourth, producing audiovisual learning media in the form of learning videos and learning tools. Fifth, the fifth step was the trial and product revision. The product developed in the form of learning videos was tested with three stages, namely (1) validation by media experts, material and learning design, (2) validation by students. In the first stage (expert test) the product analysis and revision were carried out based on the validator's assessment and comments.

\section{LITERATURE REVIEW}

\section{a. Definition Learning Media}

In the teaching and learning process, media could be used to facilitate the achievement of competency standards in the curriculum. Learning media was everything that could be used to channel messages from the sender to the recipient so as to stimulate the thoughts, feelings, attention and interests and wishes of students in such a way that the learning process occured in order to achieve learning goals effectively ${ }^{3}$.

\section{b. Definition Video Media}

Learning video media was one of the audio visual media or media viewing. Defined video learning as a medium used to stimulate students' thoughts, feelings, and willingness to learn through audio-visual display of ideas or ideas, messages, and information ${ }^{4}$. Learning video media were media or tools that provide audio and visuals that contained good learning messages that contained concepts, principles, procedures, knowledge application theories to help understanding an instructional material ${ }^{5}$.

\section{c. Thematic Learning}

Thematic learning was a model in integrated learning (integrated instruction) which was one learning system that enables students, both individually and in groups, to be actively recognized and discovered scientific concepts and principles in an authentic, holistic and meaningful way ${ }^{6}$.

Thematically was a combination of various fields of study; for example in the field of Natural Sciences, Mathematics, Religion Education, Social Sciences and others, then in the implementation, it is no longer separated but it became a holistic and intergralistic ${ }^{7}$.

\section{RESULTS AND DISCUSSION}

The results of the study showed that in fact the teacher had a great desire to develop an effective and innovative learning media that could stimulate student activity, stimulate their creativity and improve learning achievement.

There were three principles of learning, namely the change of behavior, the occurrence of a process and the experience. Experience was basically the result of the interaction between students and their environment. It took an appropriate media to maximize the learning process, one of which was with video media. However, there were some obstacles encountered in the development of video media, including the limited time for teachers to create media, limitations or lack of mastery in using video editing software, and in the end in conveying teacher learning, only utilizing existing media.

Thematic learning at SD 101732 Kampung. Lalang was still not optimal, the teacher was still fixated on printed textbooks and lecture methods. Students were less enthusiastic in learning because the learning media used by the teacher was limited to drawing on the book. So students expectation there were alternative media so that learning is more interesting. Broadly speaking, this development research was carried out through several steps, namely: 1) conducting preliminary research; 2) making video-based thematic learning media designs; 3) initial product development; 4) product revision; and 5) final products / finished products. This preliminary study included identifying learning needs, writing learning goals, determining learning experiences, formulating material, writing indicators, developing learning strategies and developing learning materials.

As for making designs to develop videos into video-based thematic learning media, can be in the form of: 1) thematic learning media; 2) lesson structure included learning titles, $\mathrm{SK}, \mathrm{KD}$, indicators, learning objectives, time, introduction, (material description), summary. The next step was to develop the initial product, then this initial product was tested (judgment) to material experts and media experts. The results of the validation of media experts obtained an average score of 3.33 media was very good and feasible to be applied in the learning process with several revisions according to suggestions. Then for the validation of the experts the learning material obtained an average score of 3.1 and according to the expert the media learning material developed was very good and feasible to be applied in the learning process with revision according to the written suggestion. The results of the validation of learning design experts obtained an average score of 3.33 media was very good and feasible to be applied in the learning process with several revisions according to suggestions. Overall from the results of the expert judgment, this media was feasible to be applied in the class V thematic learning process.

After getting suggestions for revisions, suggestions for improvement and feasibility of experts, then a trial was carried out gradually, namely the results of individual trials obtained an average score of 2.68 including the good category. Small group trials obtained an average score of 3.1 including good categories Operational trials scored 3.77 including good categories The three stages of media product trials that used students as trial subjects stated that video media was suitable for use as air theme learning media clean for health.

\section{CONCLUSION}

Based on the results of the development of thematic learning video media, the following conclusions could be drawn; Learning media in the form of thematic video class 5 on theme clean air for the health of SD 101732 Kampung. Lalang was developed through five steps of research. The five 
steps were, the analysis of the needs of the development of learning programs, the study of competency and learning material standards, the development of learning programs, producing audiovisual media in the form of learning videos, and product trials and revisions.

Learning media in the form of thematic video class $\mathrm{V}$ clean air for the health of SD Negeri 101732 Kampung. Lalang had been developed with "very high" quality based on the validation of media, material, and fifth grade students. The validation of instructional media experts showed a mean score of 3.33 with a "very high" category. Validation from class V material experts showed a score of 3.1 with the category "very high". The validation of language experts showed a mean score of 3.33 with a "very high" category. Validation of individual test phase students showed a score of 2.68 with the "high" category. Student validation of the small group test stage showed a score of 3.1 with the category "very high".

So it could be concluded that the development of learning media in the form of thematic videos in class $\mathrm{V}$ was the theme of clean air for the health of SD Negeri 101732 Kampung Lalang had been "feasible" used as a learning medium.

\section{REFERENCES}

[1] A. Majid, "Strategi Pembelajaran". Bandung. PT Remaja Rosdakary, 2013, pp. 4.

[2] D. Salma, "Prinsip Desain Pembelajaran Instructional Desain Principles", Jakarta, Kencana Prenada Media Grup, 2007, pp. 64.

[3] Sukiman, "Pengembangan Media Pembelajaran".Yogyakarta, Pedagogia, 2012, pp. 23.

[4] P. L. Putu, "Media Pembelajaran", Yogyakarta, Gava Media, 2006, pp. 4

[5] R. Cheppy, “ Pedoman Pengembangan Media Video", Jakarta, P3AI UPI, 2007, pp.2.

[6] Rusman, "Model Model Pembelajaran". Depok, PT Raja Grafindo Persada, 2013, pp.254.

[7] Trianto, Mengembangkan Model Pembelajaran Tematik.Jakarta: PT Prestasi Pustakarya, 2007, pp.117. 